\title{
Perbedaan Kadar Hemoglobin dan Morfologi Eritrosit Sebelum Menstruasi dan Setelah Menstruasi Remaja Putri
}

\author{
Risma Ayu Asfaraini, Siti Zaetun, Rohmi \\ Department of Health Analyst, Health Polytechnic of the Ministry of Health of Mataram, Indonesia \\ Email: ayurisma@yahoo.com
}

\begin{abstract}
ABSTRAK
Masa remaja ditandai dengan berfungsinya organ reproduksi seperti menstruasi. Sepanjang usia reproduktif, wanita akan mengalami kehilangan darah akibat peristiwa haid. Dengan demikian hilangnya zat besi akan menyebabkan menurunnya kadar hemoglobin dalam darah dan akan menyebabkan keadaan anemia. Tujuan penelitian ini adalah untuk mengetahui perbedaan kadar hemoglobin dan gambaran morfologi eritrosit sebelum dan setelah menstruasi pada remaja putri di Pondok Pesantren Nurul Hakim Kediri. Penelitian ini menggunakan rancangan observasional analitik. Populasi sejumlah 185 orang dan sampel sejumlah 30 orang. Teknik pengambilan sampel menggunakan non random accidental sampling. Analisis data yang digunakan adalah analisis data bivariet yang menggunakan analisis uji statistik independent T-Test. Morfologi eritrosit dianalisa secara deskribtif. Hasil penelitian didapatkan rerata kadar hemoglobin mahasiswa sebelum menstruasi $13.2 \mathrm{~g} \%$ dan setelah menstruasi 11.8 $\mathrm{g} \%$. Morfologi eritrosit sebelum menstruasi dan setelah menstruasi rata-rata ditemukan Shape (bentuk) eritrosit yang abnormal sedangkan ditinjau dari Size (ukuran), 25\% memiliki ukuran kecil (mikrositik) dan dari segi staining (pewarnaan), $47 \%$ pewarnaannya bersifat anormal. Setelah dilakukan uji T-test terdapat perbedaan rerata kadar Hemoglobin sebelum dan rerata kadar Hemoglobin setelah Menstruasi pada remaja putri yaitu kadar hemoglobin sesudah menstruasi lebih rendah dibandingkan sebelum menstruasi.
\end{abstract}

Kata Kunci: Kadar Hemoglobin, Mofologi Eritrosit, Remaja Putri, Menstruasi

\footnotetext{
ABSTRACT

Adolescence is characterized by the functioning of reproductive organs such as menstruation. Throughout the reproductive age, women will experience blood loss due to menstrual events. Thus the loss of iron will cause a decrease in hemoglobin levels in the blood and will cause anemia. This research to determine differences in hemoglobin levels and morphological features of erythrocytes before and after menstruation in young women in Nurul Hakim Kediri Islamic Boarding School. This
}

study used an observational analytic study design. The population was 185 people and a sample of 30 people. The sampling technique uses non random accidental sampling. Analysis of the data used is bivariate data analysis using independent T-Test statistical test analysis. Erythrocyte morphology is analyzed in a descriptive manner. The results showed that the average hemoglobin level of students before menstruation was $13.2 \mathrm{~g} \%$ and after menstruation $11.8 \quad \mathrm{~g} \%$. Morphology of erythrocytes before menstruation and after menstruation on average found abnormal erythrocyte Shape (shape) while in terms of Size (size), 25\% have small size (microcytic) and in terms of staining (staining), $47 \%$ of the coloring is abnormal. Conclusion after the T-test, there was a difference in the mean Hemoglobin level before and the mean Hemoglobin level after Menstruation in young women namely the hemoglobin level was lower than before menstruation.

Keywords : Hemoglobin Levels, Erythrocyte Morphology, Young Women, Menstruation

\section{Pendahuluan}

Pemeriksaan laboratorium berperan penting dalam membantu menegakkan diagnosis suatu penyakit tertentu, dan adakalanya bahkan menjadi penentu diagnosis. Pemeriksaan laboratorium tidak hanya dilakukan bagi individu yang sakit, individu sehat yang rutin melakukan pemeriksaan laboratorium akan memperoleh banyak manfaat. Pemeriksaan laboratorium dapat berupa Medical Check Up berkala sehingga individu dapat memantau terus kesehatanya. Pemeriksaan laboratorium meliputi pemeriksaan hematologi, urinalisis, kimiaklinik, dan pemeriksaan lainnya. Salah satu pemeriksaan yang lumrah dilakukan di laboratorium adalah pemeriksaan hematologi yaitu mencakup pemeriksaan yang berhubungan dengan specimen darah diantaranya adalah pemeriksaan kadar hemoglobin dalam 
darah. Hemoglobin adalah protein yang terkonjugasi yang terdapat dalam sel darah merah yang mengandung zat besi dan berfungsi sebagai pengangkutan oksigen dari paru-paru ke semua sel jaringan tubuh.Hemoglobin terdiri dari heme dan globin. Heme adalah gugus prostetik yang terdiridari atom besi, sedangkan globin adalah protein yang dipecah menjadi asam (Kiswari, 2014). Kadar hemoglobin dalam darah merupakan salah satu pemeriksaan skrining yang dilakukan untuk menentukan apakah seorang mengalami anemia atau tidak. Dalam pemeriksaan hemoglobin darah ada beberapa metode yang digunakan diantaranya yaitu metode sahli, metode stik, metode analyzer, metode cyanmet dan lainnya.

Apabila kadar hemoglobin yang diperiksa dalam darah berada di bawah normal (batas normal kadar hemoglobin yaitu sekitar 12-13 g\%), seseorang belum dapat dipastikan mengalami anemia. Namun perlu dilakukan pemeriksaan penunjang lainnya seperti melihat morfologi eritrosit pada apusan darah tepi untuk memastikan adanya kelainan eritrosit atau tidak dalam rangka menunjang diagnose hasil uji skrining. Diperkirakan prevalensi anemia secara global sekitar 51\%. Sedangkan perbandingan prevalensi untuk anak balita sekitar 43\%, anak sekolah 37\%, laki-laki dewasa hanya $18 \%$, dan prevalensi anemia pada wanita berkisar 13,4-87,5\%. Hal ini meunjukkan prevalensi anemia yang cukup tinggi pada wanita terutama pada wanita yang menginjak masa remaja (Wahyuningsih and Astuti, 2012).

Remaja merupakan masa peralihan dari anak-anak ke masa dewasa. Kategori masa remaja dari berbagai referensi berbedabeda, namun WHO menetapkan remaja (adolescent) berusia antara 10-19 tahun (Briawan, 2013). Masa remaja ditandai dengan perubahan baik fisiologi maupun psikologi. Perubahan fisiologi diantaranya ditandai dengan berfungsinya organ reproduksi seperti menstruasi. Lamanya menstruasi berkisar 3-5 hari, atau dengan variasi yang berbeda, banyaknya darah yang keluar dalam satu periode menstruasi berkisar rata-rata $50 \mathrm{ml}$. Jika lebih dari $80 \mathrm{ml}$ maka dianggap patologis. Sepanjang usia reproduktif, wanita akan mengalami kehilangan darah akibat peristiwa haid. Darah akan kehilangan zat besi sebesar 12,5-15 mg/bulan, atau kira-kira sama dengan 0,4- 0,5 mg/hari. Dengan demikian hilangnya zat besi akan menyebabkan menurunnya kadar hemoglobin dalam darah dan akan menyebabkan keadaan anemia (Arisman, 2007). Oleh karena itu penting bagi remaja untuk memperhatikan asupan zat gizi terutama zat besi. Zat besi sangat diperlukan untuk memenuhi zat besi yang hilang pada saat menstruasi. Zat besi berfungsi untuk memproduksi hemoglobin dan sel darah merah yang diperoleh dari makanan seharihari (Briawan, 2013). Faktanya dilingkungan pondok pesantren, santriwati kurang memperhatikan pola makan. Dikarenakan makanan yang disediakan setiap harinya kurang bervariasi, sehingga tak jarang ditemukan santriwati yang memiliki pola makan yang tidak teratur. Menu yang paling sering disediakan tiap harinya adalah tempe, padahal protein pada tempe tergolong mudah dicerna sehingga protein dapat digunakan untuk membentuk hemoglobin bersama dengan besi atau senyawa lain. Proses pembentukan hemoglobin dalam sumsum tulang belakang juga memerlukan vitamin B12, asam folat, protein, zat besi, $\mathrm{Cu}$ dan $\mathrm{Zn}$, yang semuanya terdapat dalam tempe (Astuti, Aminah and Syamsianah, 2014). Kurangnya pengetahuan tentang kebutuhan zat besi dan kandungan zat besi pada makanan, hal inilah yang menyebabkan banyak santriwati yang enggan untuk memperhatikan pola makan terutama pola asupan zat besi.

Berdasarkan latar belakang pemikiran tersebut diatas, penulis ingin meneliti tentang "Perbedaan Kadar Hemoglobin dan Morfologi Eritrosit Sebelum Menstruasi dengan Setelah Menstruasi Pada Remaja Putri di Pondok Pesantren Nurul Hakim Kediri”..

Tabel 4.2 Distribusi kelompok nilai kadar hemoglobin sebelum menstruasi

\begin{tabular}{|l|l|l|l|}
\hline No & Kadar Hemoglobin & Frekuensi $(n)$ & Persentase (\%) \\
\hline I. & Normal & 12 & 80 \\
\hline 2. & Rendah & 3 & 20 \\
\hline \multicolumn{2}{|l|}{ Iumlah } & 15 & 100 \\
\hline
\end{tabular}


Tujuan penelitian ini adalah untuk mengetahui perbedaan kadar hemoglobin dan morfologi eritrosit sebelum menstruasi dengan setelah menstruasi pada remaja putri di Pondok Pesantren Nurul Hakim Kediri.

\section{Metode Penelitian}

Penelitian ini merupakan penelitian yang menggunakan rancangan observasional analitik. Populasi dalam penelitian ini sejumlah 185 orang dengan sampel sejumlah 30 orang. Teknik pengambilan sampel menggunakan non random accidental sampling. Sampel diambil dari dua kelompok yaitu kelompok pertama, pengambilan sampel dilakukan 7 hari sebelum menstruasi dan kelompok kedua, pengambilan sampel dilakukan 7 hari setelah menstruasi setelah itu semua sampel diperiksa kadar hemoglobinnya menggunakan metode Strip $\mathrm{Hb}$ meter kemudian dilakukan pemeriksaan morfologi eritrosit yang diperiksa dari pengamatan apusan darah tepi. Hasil pemeriksaan disajikan dalam bentuk tabel kemudian data yang diperoleh di analisis menggunakan analisis data bivariet untuk pemeriksaan hemoglobin yang menggunakan analisis uji statistik independent t-Test dengan membandingkan kadar hemoglobin sebelum menstruasi dan setelah menstruasi, sedangkan morfologi eritrosit dianalisa secara deskribtif

\section{Hasil Penelitian dan Pembahasan}

Berdasarkan penelitian yang telah dilakukan didapatkan nilai kadar hemoblobin dan morfologi eritrosit dimana spesimen darah kapiler diambil 7 hari sebelum menstruasi dan 7 hari setelah menstruasi pada remaja putri di pondok dapat dilihat pada tabel berikut:

Tabel 4.1 Distribusi kelompok nilai kadar hemoglobin sebelum menstruasi.

Berdasarkan tabel 4.1 tentang kadar hemoglobin sebelum menstruasi, sebagian besar responden memiliki nilai kadar hemoglobin normal yaitu sebanyak 12 responden dengan persentase $80 \%$ dan sisanya yaitu 3 responden dengan persentase $20 \%$ memiliki nilai kadar hemoglobin yang cenderung rendah.
Tabel 4.2 Distribusi kelompok nilai kadar hemoglobin setelah menstruasi.

Berdasarkan tabel 4.2 tentang kadar hemoglobin setelah menstruasi, diperoleh sebanyak 9 responden dengan persentase $60 \%$ memiliki nilai kadar hemoglobin yang normal dan 6 responden lainnya dengan persentase $40 \%$ memiliki nilai kadar hemoglobin yang rendah.

\begin{tabular}{|l|l|l|l|}
\hline No. & Kadar Hemoglobin & Frekuensi (n) & Persentase (\%) \\
\hline I. & Normal & 9 & 60 \\
\hline 2. & Rendah & 6 & 40 \\
\hline \multicolumn{2}{|c|}{ lumlah } & 15 & 100 \\
\hline
\end{tabular}

\section{Analisa Bivariat}

Berdasarkan tabel 4.7 tentang hasil perbedaan kadar hemoglobin sebelum menstruasi dengan kadar hemoglobin setelah menstruasi dari 15 responden kelompok sebelum menstruasi yang diberikan kode A dan 15 responden untuk kelompok setelah menstruasi yang diberikan kode B. Pada pemeriksaan kadar hemoglobin sebelum mentruasi diperoleh nilai hemoglobin tertinggi yaitu $16.1 \mathrm{~g} \%$ dan nilai hemoglobin

Tabel 4.7 Hasil Penelitian Kadar Hemoglobin Sebelum Menstruasi Dan Setelah Menstruasi Pada Remaja Putri di Pondok Pesantren Nurul Hakim Kediri

\begin{tabular}{|c|c|c|c|}
\hline \multicolumn{4}{|c|}{ Kadar Hemoglobin } \\
\hline Kode $A$ & Sebelum Menstruasi ( $\mathrm{g} \%)$ & Kode B & Setelah Menstruasi (g\%) \\
\hline I. & 15.2 & I. & 12.2 \\
\hline 2. & 12.3 & 2. & 13.2 \\
\hline 3. & 11.4 & 3. & 11.2 \\
\hline 4. & 11.6 & 4. & 11.3 \\
\hline 5. & 13.9 & 5. & 12.7 \\
\hline 6. & 11.8 & 6. & 13.6 \\
\hline 7. & 13.8 & 7. & 11.5 \\
\hline 8. & 13.6 & 8. & 12.3 \\
\hline 9. & 12.8 & 9. & 13.6 \\
\hline 10. & 16.1 & 10. & 10.1 \\
\hline II. & 14.7 & II. & 12.3 \\
\hline 12. & 14.3 & 12. & 13.1 \\
\hline 13. & 12.0 & 13. & 12.9 \\
\hline 14. & 13.3 & 14. & 7.9 \\
\hline 15. & 12.2 & 15. & 10.5 \\
\hline Total Rerata & 13.2 & Total Rerata & 11.8 \\
\hline
\end{tabular}

terendah yaitu $11.4 \mathrm{~g} \%$ dengan nilai rata-rata adalah $13.2 \mathrm{~g} \%$. Sedangkan nilai tertinggi dari pemeriksaan kadar hemoglobin setelah menstruasi yaitu $13.6 \mathrm{~g} \%$ dan nilai terendahnya adalah $7.9 \mathrm{~g} \%$. dengan nilai rata-rata adalah $11.8 \mathrm{~g} \%$. Hasil uji statistic T-test yang didapatkan adalah $\mathrm{p}=0.032$ $(\mathrm{p}<0.05)$ 
Uji statistik yang digunakan adalah $\mathrm{T}$-test dengan nilai rata-rata yang didapatkan dari kelompok remaja putri sebelum menstruasi adalah $13.2 \mathrm{~g} \%$ dan nilai rata-rata yang didapatkan dari kelompok remaja putri setelah menstruasi adalah $7.9 \mathrm{~g} \%$. Berikut adalah hasil uji statistiknya:

Dari uji statistik yang telah dilakukan didapatkan nilai signifikan $(\mathrm{p}=0.032)$ adalah lebih kecil dari pada nilai alpha $(\mathrm{A}=0.05)$. Hal ini menunjukka bahwa Ha diterima dan Ho ditolak artinya adanya perbedaan kadar hemoglobin sebelum menstruasi dan setelah menstruasi.

Berdasarkan tabel 4.4 tentang morfologi eritrosit sebelum menstruasi yang diamati dengan memperhatikan 3 komponen diantaranya yaitu Shape (bentuk), Size (ukuran), dan Staining (pewarnaan), diperoleh seluruh responden sebelum menstruasi sebanyak 15 responden rata-rata ditemukan Shape (bentuk) eritrosit yang abnormal diantaranya yaitu Eliptosit, Stomatosit, Burr sell dan Sel target (sel sasaran) sedangkan ditinjau dari Size (ukuran), 4 responden (A3, A4, A6, dan A12) memiliki ukuran kecil (mikrositik) dan 11 responden lainnya memiliki ukuran yang normal (normositik). Dari segi staining (pewarnaan), 4 responden (A3, A4, A6, dan A9) pewarnaannya bersifat hipokromik, 2 responden (A2 dan A15) pewarnaannya bersifat hiperkromik dan 9 responden lainnya pewarnaannya bersifat normokromik.

Berdasarkan tabel 4.5 tentang morfologi eritrosit setelah menstruasi yang diamati dengan memperhatikan 3 komponen diantaranya yaitu Shape (bentuk), Size (ukuran), dan Staining (pewarnaan), diperoleh seluruh responden setelah menstruasi sebanyak 15 responden rata-rata ditemukan Shape (bentuk) eritrosit yang abnormal diantaranya yaitu Eliptosit, Stomatosit, Burr sell dan Sel target (sel sasaran) sedangkan ditinjau dari Size (ukuran), 6 responden (B3, B4, B7, B8, B10, B14 dan B15) memiliki ukuran kecil (mikrositik) dan 9 responden lainnya memiliki ukuran yang normal (normositik). Dari segi staining (pewarnaan), 5 responden
(B3, B4, B10, B14 dan B15) pewarnaannya bersifat hipokromik, 3 responden (B1, B7 dan B9) pewarnaannya bersifat hiperkromik dan 7 responden lainnya pewarnaannya bersifat normokromik.

\section{Pembahasan}

Hasil pemeriksaan urine metode carik celup pada parameter glukosa, leukosit esterase, nitrit, dan eritrosit adalah sebagai berikut: 1.Kadar Hemoglobin.

Berdasarkan tabel 4.1 mengenai distribusi kadar hemoglobin sebelum menstruasi didapatkan 12 responden dengan persentase $80 \%$ memiliki kadar hemoglobin normal dan 3 responden dengan persentase $20 \%$ memiliki kadar hemoglobin yang rendah. Dari data kadar hemoglobin yang ada pada tabel 4.7, diperoleh nilai tertinggi dari 15 responden yaitu $16.1 \mathrm{~g} \%$ dan nilai terendah dari 15 responden yaitu 11.4 $\mathrm{g} \%$ dengan total rerata seluruhnya adalah $13.2 \mathrm{~g} \%$.

Distribusi kadar hemoglobin setelah menstruasi pada tabel 4.2 didapatkan sebanyak 9 responden dengan persentase $60 \%$ memiliki kadar hemoglobin normal dan 6 responden lainnya dengan persentase $40 \%$ memiliki kadar hemoglobin yang rendah. Dilihat dari data kadar hemoglobin setelah mentruasi yang terdapat pada tabel 4.7, diperoleh nilai tertinggi dari 15 responden yaitu $13.6 \mathrm{~g} \%$ dan nilai terendah dari 15 responden yaitu $7.9 \mathrm{~g} \%$ dengan total rerata seluruhnya adalah $11.8 \mathrm{~g} \%$.

Berdasarkan hasil uji statistik didapatkan nilai signifikan $(\mathrm{p}=0.032)$ yang lebih kecil dari nilai alpha $(\mathrm{A}=0.05)$ yang berarti terdapat perbedaan kadar hemoglobin sebelum menstruasi dengan kadar hemoglobin setelah menstruasi dimana nilai total rerata kadar hemoglobin setelah menstruasi lebih rendah dari nilai total rerata kadar hemoglobin sebelum menstruasi dengan selisih 1.37.

Menurut peneliti, total rerata nilai kadar hemoglobin setelah menstruasi lebih rendah dari total rerata nilai kadar hemoglobin sebelum menstruasi dan berdasarkan penelitian sebelumnya oleh Nugrahani Ika (2013) terdapat perbedaan 
kadar Hemoglobin sebelum dan sesudah Menstruasi pada mahasiswa DIII Keperawatan Universtas Muhamadiyah Surakarta, yaitu kadar hemoglobin sesudah menstruasi lebih rendah dibandingkan sebelum menstruasi.

Briawan (2013) mengemukakan bahwa pada saat mulai menstruasi remaja putri akan kehilangan banyak darah, rata-rata kehilangan darah pada saat menstruasi 84 $\mathrm{ml}$, dengan asumsi kehilangan $\mathrm{Hb} 133 \mathrm{~g} / \mathrm{l}$, sehingga remaja putri membutuhkkan tambahan zat besi $0.56 \mathrm{mg} /$ hari. Zat besi memiliki peranan penting di dalam tubuh diantaranya yaitu untuk memproduksi hemoglobin dan sel darah merah dan membantu berbagai proses metabolisme. Sebenarnya, darah mengandung zat besi yang dapat didaur ulang. Akan tetapi kehilangan darah yang cukup banyak, seperti saat menstruasi dapat menghilangkan zat besi dari dalam tubuh.

Jumlah zat besi yang cenderung sedikit di dalam tubuh hanya sekitar (3-5 g) (Briawan, 2013). Sedangkan kebutuhan yang cukup banyak pada saat menstruasi menyebabkan remaja putri banyak yang mengalami defisiensi besi akibatnya kadar hemoglobin akan menurun dan akan terjadi anemia defisiensi besi. Jika ditinjau dari masing-masing responden terdapat sekitar 3 responden dengan persentase $20 \%$ dari kelompok remaja putri sebelum menstruasi dan 6 responden dengan persentase $40 \%$ dari kelompok remaja putri setelah menstruasi memiliki kadar HB yang yang cukup rendah.

Kadar hemoglobin yang rendah pada umumnya disebabkan karena beberapa faktor diantaranya menurut Fithra di dalam buku "Permasalahan Gizi Pada Remaja Putri" (2014) secara umum faktor penyebab penurunan kadar $\mathrm{Hb}$ yang merupakan diagnose awal anemia diantaranya yaitu kurangnya asupan zat besi $(\mathrm{Fe})$ dan protein. Kandungan zat besi pada makanan hewani lebih banyak daripada kandungan zat besi pada makanan nabati. Berdasarkan hasil penelitian di Vietnam menyatakan bahwa ada hubungan antara peningkatan kadar hemoglobin seiring dengan frekuensi konsumsi protein yang bersumber dari asupan makanan hewani.

Jika dilihat dari kehidupan santriwati atau remaja putri di lingkungan
Pondok Pesantren Nurul Hakim penyediaan makanan hewani sangat jarang hampir bisa dipastikan penyediaan makanan hewani dilakukan hanya saat hari-hari besar saja misalnya ketika hari raya qurban dan harihari besar lainnya. Menu makanan yang paling sering bahkan dapat dikatakan menu wajib ketika makan adalah menu olahan dari tempe, penyediaan makanan yang kurang bervariasi dan cara pengolahan yang kurang maksimal menyebabkan banyak santriwati yang tidak mau makan sehingga tidak memperhatikan pola makan terutama pola asupan zat besi. Walaupun pada makanan nabati kandungan zat besinya sedikit akan tetapi penting bagi remaja putri untuk mengkonsumsi olahan tempe yang disediakan. Untuk membantu sebagian kecil kebutuhan zat besi apalagi saat menstruasi. Protein pada tempe tergolong mudah dicerna sehingga protein dapat digunakan untuk membentuk hemoglobin bersama dengan besi atau senyawa lain. Proses pembentukan hemoglobin dalam sumsum tulang belakang juga memerlukan vitamin $\mathrm{B} 12$, asam folat, protein, zat besi, $\mathrm{Cu}$ dan $\mathrm{Zn}$, yang semuanya terdapat dalam tempe (Astuti, Aminah and Syamsianah, 2014).

Zat besi yang bersumber dari makanan belum cukup untuk memenuhi kekurangan zat besi ketika menstruasi, oleh karena itu disarankan agar remaja putri mengkonsumsi tablet $\mathrm{Fe}$ yang disediakan dari puskesmas setempat. Faktor lain penyebab penurunan kadar $\mathrm{Hb}$ antara lain malabsorpsi zat besi pada saluran cerna akibat gastritis, ulkus peptikum, diare, dan adanya parasit cacing tambang. Infeksi akibat penyakit kronis maupun sistemik misalnya HIV dan AIDS serta penyakit lain seperti malaria juga merupakan faktor penyebab lainnya.(Briawan, 2013)

Berdasarkan hasil penelitian yang
dilakukan tentang morfologi eritrosit
sebelum menstruasi dan setelah menstruasi
yang diamati dengan memperhatikan 3
komponen, diantaranya yaitu Shape
(bentuk), Size (ukuran), dan Staining
(pewarnaan), diperoleh seluruh responden
sebelum menstruasi sebanyak 15 responden
dan 15 responden setelah menstruasi rata-
rata ditemukan Shape (bentuk) eritrosit yang
abnormal diantaranya yaitu Eliptosit,


Stomatosit, Burr sell dan Sel target (sel sasaran)

Istilah umum untuk eritrosit dewasa yang memiliki variasi bentuk eritrosit selain bentuk normal, dalam apusan darah tepi disebut poikilositosis. Deviasi bentuk eritrosit merupakan suatu perubahan kimia atau fisik baik pada membran sel ataupun sitoplasma. Dalam beberapa kasus mekanismenya belum diketahui. Namun, penelitian terakhir dalam biologi sel telah memberikan kontribusi terhadap peningkatan pengetahuan dari mekanisme ini. Setiap poikilosit dapat ditemukan dalam jumlah yang meningkat pada gangguan hematologi spesifik maupun nonhematologi (Kiswari, 2014).

Bedasarkan hasil penelitian ditemukan kelainan bentuk eritrosit yaitu Pertama, Eliptosit merupakan eritrosit yang berbentuk memanjang, seperti batang, cerutu, atau sosis. Eliptosit merupakan cacat membran. Terjadi peningkatan apabila terdapat gangguan klinis yang terkait termasuk eliptositosis herediter, anemia terkait dengan keganasan, penyakit hemoglobin $\mathrm{C}(\mathrm{HbC})$, anemia hemolitik (kadang-kadang), anemia defisiensi besi, anemia pernisiosa, anemia sel sabit dan talasemia. Kedua yaitu Burr sell (sel burr) merupakan eritrosit yang menunjukkan tonjolan-tonjolan pendek pada membrane sel. Sel-sel ini sering memanjang tidak teratur. Secara klinis sel burr meningkat dalam berbagai jenis anemia, perdarahan ulkus lambung, karsinoma lambung, tukak lambung, inusufiensi ginjal, defisiensi piruvat kinase, dan uremia (Kiswari, 2014).

Variasi bentuk eritrosit yang

lain yang ditemukan yaitu Sel target (sel sasaran) merupakan sel eritrosit abnormal yang berbentuk seperti lonceng yang meningkat pada penderita talasemia sel sabit, hemoglobinopati $(\mathrm{HbC})$, anemia hemolitik dan penyakit hati. Selanjutnya yaitu Stomatosit merupakan sel eritrosit abnormal yang tampak sebagai eritrosit dengan bagian pucatnya sebagai celah (tidak bundar) Ditemukan pada penderita alkoholisme akut, alkoholisme sirosis, defisiensi glutation, keracunan logam berat, keganasan dan talasemia mayor (Kiswari, 2014).
Hasil pengamatan berdasarkan Size (ukuran), pada kelompok remaja putri sebelum menstruasi ditemukan 4 responden (A3, A4, A6, dan A12) memiliki ukuran kecil (mikrositik) dan

11 responden lainnya memiliki ukuran yang normal (normositik). Sedangkan pada kelompok remaja putri setelah menstruasi didapatkan 6 responden $(\mathrm{B} 3, \mathrm{~B} 4, \mathrm{~B} 7, \mathrm{~B} 8$, B10, B14 dan B15) memiliki ukuran kecil (mikrositik) dan 9 responden lainnya memiliki ukuran yang normal (normositik).

Kiswari (2014) pada bukunya yang berjudul "Hematologi dan Transfusi" menyebutkan bahwa eritrosit normal memiliki diameter rata-rata $7,2 \mathrm{~mm}$ dengan variasi 6,8-7,5 mm. ukuran eritrosit normal disebut normositik. Adapun ukuran yang lebih kecil dari normal disebut mikrositik. Variasi ukuran yang ditemukan pada penelitian ini adalah normositik dan mikrositik. Ukuran yang lebih kecil dari ukuran normal atau disebut mikrositik dikaitkan dengan penurunan sintesis hemoglobin. Penurunan hemoglobin dapat disebabkan oleh defisiensi besi baik karena menstruasi maupun kurangnya asupan zat besi, gangguan sintesis globulin, atau kelainan mitokondria yang mempengaruhi sintesis heme pada molekul hemoglobin. Adapun gangguan yang dapat menyebabkan mikrositosis meliputi sindrom malabsorbsi, anemia defisiensi besi, variasi jenis hemoglobin, yaitu pada hemoglobinopati.

Berdasarkan hasil penelitian ditinjau dari segi staining (pewarnaan), dari 15 responden pada kelompok remaja putri sebelum menstruasi didapatkan 4 responden (A3, A4, A6, dan A9) pewarnaannya bersifat hipokromik, 2 responden (A2 dan A15) pewarnaannya bersifat hiperkromik dan 9 responden lainnya pewarnaannya bersifat normokromik. Sedangkan dari 15 responden pada kelompok remaja putri setelah menstruasi didapatkan 5 responden (B3, B4, B10, B14 dan B15) pewarnaannya bersifat hipokromik, 3 responden (B1, B7 dan B9) pewarnaannya bersifat hiperkromik dan 7 responden lainnya pewarnaannya bersifat normokromik.

\section{Kesimpulan}

Eritrosit normal memiliki penampilan berwarna merah dengan bagian 
pusat berwarna leih terang (pucat) ketika diwarnai dengan pewarnaan konvensional. Warna merah merupakan refleksi banyaknya hemoglobin dalam sel. Warna pucat ditengah merupakan bagian yang tipis dari sel, diameter normal tidak kurang dari sepertiga dan juga tidak melebihi sepertiga dari diameter keseluruhan sel dan disebut sebagai central pallor. Eitrosit yang normal itu disebut normokromik. Variasi warna normal atau abnormal menunjukkan kandungan sitoplasmanya. Istilah umum untuk variasi warna adalah anisokromia. Hipokromik terjadi karena cadangan besi tidak memadai, sehingga menyebabkan penurunan sintesis hemoglobin. Eritrosit akan tampak pucat pada penderita defisiensi hemoglobin, Hipokrom terkait dengan anemia defisiensi besi. Adapun hiperkromik terjadi karena konsentrasi hemoglobinnya lebih dari normal atau terjadi ketidakseimbangan sel (Kiswari, 2014). Pewarnaan yang bersifat hipokromik ditandai dengan daerah tepi yang terisi lebih banyak hemoglobin (warna merah) menjadi lebih tipis daripada sel normokromik (Kokasih E.N. dan A.S Kosasih, 2005).

Berdasarkan hasil penelitian dapat disimpulkan bahwa rerata kadar hemoglobin mahasiswa sebelum menstruasi $13.2 \mathrm{~g} \%$ dan setelah menstruasi $11.8 \mathrm{~g} \%$. Setelah dilakukan uji $\mathrm{T}$ - test terdapat perbedaan rerata kadar Hemoglobin sebelum dan rerata kadar Hemoglobin setelah Menstruasi pada remaja putri yaitu kadar hemoglobin sesudah menstruasi lebih rendah dibandingkan sebelum menstruasi. Morfologi eritrosit sebelum menstruasi dan setelah menstruasi rata-rata ditemukan Shape (bentuk) eritrosit yang abnormal sedangkan ditinjau dari Size (ukuran), 25\% memiliki ukuran kecil (mikrositik) dan dari segi staining (pewarnaan), $47 \%$ pewarnaannya bersifat anormal.

\section{Daftar Pustaka}

Arief, M. (2007) Histologi Umum Kedokteran. Cet I. Surakarta: LPP UNI dan UNS Press. Baron. Arisman. (2007). Gizi dalam Daur Hidup. Jakarta: Penerbit Buku Kedokteran.।

Astuti, R., Aminah, S. and Syamsianah, A. (2014) 'Komposisi Zat Gizi Tempe Yang Difortifikasi Zat Besi Nutritional Composition Of Soyben Tempeh Fortified With Iron And Vitamin A On Uncook And Cook Soyben Tempeh',
Program Studi Kesehatan Masyarakat, Fakultas Kesehatan Masyarakat, Universitas Muhammadiyah Semarang, 34(2), pp. 151159.

Briawan, D. (2013) Briawan, D. Jakarta: Buku Kedokteran EGC.

Depkes, R. (2008) 'Pedoman Praktik Laboratorium Kesehatan yang Benar'. Jakarta: Katalog dalam terbitan (KDT), p. 14.

Dieny, F. F. (2014). Permasalahan Gizi Pada Remaja Putri. Yogyakarta: Graha Ilmu. Evelyn, C. (2009) Anatomi dan Fisiologis untuk Paramedis. Jakarta: Gramedia.

Fatimah Siti (2009) 'Studi Kadar Klorofil Dan Zat Besi (Fe) Pada Beberapa Jenis Bayam Terhadap Jumlah Eritrosit Tikus Putih ( Rattus Norvegicus ) Anemia', Jurusan Biologi Fakultas Sains Dan Teknologi Universitas Islam Negeri (Uin) Maulana Malik Ibrahim Malang Malang.

Felicia, Hutagaol, E. and Kundre, R. (2015) 'Hubungan Status Gizi dengan Siklus Menstruasi pada Remaja Putri di PSIK UNSRAT Manado', Jurnal Keperawatan (eKp), 3(1), pp. 1-7.

Fithra, F. (2014) Permasalahan Gizi pada Remaja Putri. Yogyakarta: Graha Ilmu Gandasoebrata, R. (2010) Penuntun Laboratorium Klinik. 16th edn. Jakarta: Dian Rakyat.

Gunadi Valerie I. R, Mewo Yanti M, dan Tiho Murniati, (2016). Gambaran Kadar Hemoglobin pada Pekerja Bangunan, Fakultas Kedokteran Universitas Sam Ratulangi Manado, Volume 4, Nomor 2.

Hariwibowo, H. dan (2008) Asuhan Keperawatan pada Klien dengan Gangguan Sistem Hematologi. Jakarta: Salemba Medika.

Kandou, P. R. D., Tombokan, K. C. and Pangemanan, D. H. C. (2017) 'Hubungan antara stres dan pola siklus menstruasi pada mahasiswa Kepaniteraan Klinik Madya ( co-assistant )', di RSUP Prof. Dr. R. D. Kandou Manado, Fakultas Kedokteran Universitas Sam Ratulangi Manado,Volume 5, Nomor 1.

Kiswari, R. (2014) Hematologi dan Transfusi. Edited by $\mathrm{R}$. Carolin, $\mathrm{S}$ dan Astikawati. Jakarta: Penerbit Erlangga.

Kosasih, E. N. and Kokasih, A. S. (2005). Tafsiran Hasil Pemeriksaan Laboratorium Klinik. Tangerang: KARISMA Publishing Group.

Mahmud. 2011. Metode Penelitian Pendidikan. Bandung: Pustaka Setia. Notoatmodjo, S. 2012. Metodologi Penelitian Kesehatan. Rineka Cipta, Jakarta

Nugrahani, I., 2013 Perbedaan kadar hemoglobin sebelum dan sesudah menstruasi pada mahasiswa diii keperawatan universitas muhamadiyah surakarta, Fakultas Ilmu Kesehatan Universitas Muhammadiyah Surakarta.

Nuraini, S. 2018 Perbedaan Kadar Hemoglobin Sebelum Menstruasi Dan Pasca Menstruasi, STIKES ICMe Jombang Prodi DIII Analis Kesehatan

Prastika, D. A. 2011. Hubungan Lama Menstruasi Terhadap Kadar Hemoglobin Pada Remaja 
Siswi Sma N 1 Wonosari, Ilmiah Kt, Studi P, Kebidanan Di V, Fakultas Kedokteran

Tahir, Z., Warni, E. and Suyuti, A. (2012) 'Analisa Metode Radial Basis Function Jaringan Saraf Tiruan untuk Penentuan Morfologi Sel Darah Merah (Eritrosit) Berbasis Pengolahan Citra'.

Wahyuningsih, A. and Astuti, S. P. (2012) 'Hubungan Kadar Hemoglobin Dengan Keteraturan Siklus Menstruasi Pada Mahasiswi Prodi D III Kebidanan Tingkat III Stikes Muhammadiyah Klaten', Involusi Kebidanan, 2(3), pp. 34-45.

Yan, LT. : A Rapid Method of Preparing Smears from Effusion and Solid Mass Aspirates for Cytologic Diagnosis. Am. J. Clin Pathol 47:797-801, 1967.

Zarianis. 2006. Efek Suplementasi Besi-Vitamin C Dan Vitamin C Terhadap Kadar Hemoglobin The Effect Of Iron-Vitamin C And Vitamin C. Tesis program magister gizi masyarakat Universitas Diponegoro Semarang. http://eprints.undip.ac.id/15967/1/zarianis.pdf. diaksespada tanggal 16 Agustus 2010. 